\title{
PERBEDAAN ANTROPOLOGI HUKUM DENGAN SOSIOLOGI HUKUM DAN HUKUM ADAT
}

\author{
Muhammad Sander Aviv \\ Email: sanderaviv12@gmail.com \\ No BP: 2110003600213 \\ Fakultas Hukum Universitas Eka Sakti Padang
}

\section{A. PENDAhuluan}

Antropologi merupakan ilmu pengetahuan tentang manusia. Antropologi hukum ialah ilmu pengetahuan yang berkaitan dengan manusia yang dikaitkan dengan hukum. Manusia yang dimaksud merupakan manusia yang hidup dalam masyarakat, baik masyarakat yang masih sederhana maupun masyarakat yang sudah maju budayanya. Budaya yang dimaksud merupakan budaya hukum. Budaya hukum adalah segala bentuk perilaku maupun tingkah laku budaya manusia berpengaruh pada masalah hukum.

Antropologi sebagai ilmu terus berkembang, tidak hanya pada tataran teoritis, tetapi juga sebagai ilmu terapan yang dapat memberikan kontribusi bagi pengambil kebijakan dalam mendefinisikan kebijakan. Seperti disiplin ilmu, antropologi juga merupakan multidisiplin dalam mengkaji manusia secara utuh. Secara historis, antropologi telah berkembang dalam menjelaskan dengan bentuk laporan tentang kehidupan manusia di daerah tempat para penjelajah berkunjung, atau kehidupan salah satu dari suku negara tinggal di koloni.

Antropologi melihat hukum sebagai suatu aspek dari kebudayaan yaitu suatu aspek yang digunakan oleh kekuasaan masyarakat yang mengatur perilaku manusia dan masyarakat yang diharapkan agar tidak terjadi penyimpangan dan agar penyimpangan yang terjadi dapat diperbaiki. 
Adat masyarakat yang menjadi suatu sistem kontrol sosial itu diharapkan menjadi kekuatan hukum, apabila digunakan oleh kekuasaan masyarakat.

Antropologi hukum pada dasarnya mempelajari hubungan berbalik antara hukum dengan fenomena ataupun peristiwa sosial secara suatu sumber pengetahuan yang diperoleh dari observasi atau percobaan dalam kehidupan masyarakat; bagaimana hukum yang berfungsi dalam kehidupan masyarakat, atau bagaimana suatu hukum yang bekerja sebagai alat pengendalian sosial ataupun sarana untuk menjaga keteraturan sosial dalam masyarakat.

Antropologi hukum merupakan kajian antropologis pada makna sosial terhadap pentingnya hukum yang dilakukan dengan menelaah bagaimana suatu hukum dibuat dan terbentuk dan bagaimana pembuatan hukum tersebut dalam konteks sosial, serta bagaimana membangun hukum dalam perilaku sosial. Dengan kata lain, kajian antropologi Hukum ialah dengan memperhatikan aspek kebudayaan manusia yang berkaitan dengan fenomena suatu hukum dalam fungsinya sebagai sarana memelihara ketertiban sosial atau sebagai sarana pengendalian sosial.

Antropologi berkembang baik di negara-negara Eropa Barat, Amerika maupun di Asia. Beberapa cabang antropologi yang dikenal secara luas saat ini adalah antropologi fisik atau biologi, antropologi sosial, dan antropologi budaya.

Pada bidang lain hukum dipelajari sebagai suatu bentuk proses sosial yang berlangsung dalam kehidupan bermasyarakat. Yang mana hukum dalam secara empiris dapat dijelaskan, sebagai hukum yang berlaku dalam masyarakat selain terwujud dalam bentuk perundangundangan (hukum positif), juga berwujud sebagai hukum agama dan hukum adat. Oleh karenanya dalam memahami kajian hukum antropologi juga harus dilakukan pemahaman terhadap ilmu sosial yang berkaitan dengan ilmu hukum seperti sosiologi hukum dan hukum adat. 


\section{B. PEMBAHASAN}

Antropologi hukum adalah pembidangan antropologi budaya yang secara khusus mengkaji perilaku manusia dalam kaitannya dengan aturan hukum. Aturan hukum yang dimaksud tidak terbatas pada hukum normatif, tetapi juga mencakup hukum adat dan budaya perilaku manusia. Walaupun merupakan evolusi dari antropologi budaya, antropologi hukum bukanlah etnosentrisme. Artinya, tidak terbatas pada budaya tertentu. Tujuan dari penelitian ini adalah untuk melihat hubungan antara hukum dengan aspek budaya dan organisasi sosial.

Dari sudut pandang antropologis, hukum merupakan bagian integral dari keseluruhan kebudayaan, sehingga dipelajari sebagai produk interaksi sosial yang dipengaruhi oleh aspek kebudayaan lain seperti politik, ekonomi, ideologi, agama dan lainnya. Di sisi yang lain hukum juga dipelajari sebagai proses sosial yang berlangsung dalam kehidupan masyarakat. Ini berarti secara empiris dapat dijelaskan, bahwa hukum yang berlaku dalam masyarakat selain terwujud dalam bentuk perundang-undangan (hukum positif), juga berwujud sebagai hukum agama dan hukum adat. Tetapi, secara antropologis bentuk mekanisme-mekanisme pengaturan sendiri dalam komunitas-komunitas masyarakat adalah juga merupakan hukum yang secara lokal berfungsi sebagai sarana untuk menjaga keteraturan sosial. Dengan demikian penelitian terhadap unsur lokal dan pengaruhnya terhadap pemberlakuan sebuah hukum perlu dilakukan.

Sosiologi hukum merupakan studi hukum dalam perspektif ilmu sosial merupakan sebuah ikhtiar melakukan konstruksi hukum yang didasarkan pada fenomena sosial yang ada. Perilaku masyarakat yang dikaji adalah perilaku yang timbul akibat berinteraksi dengan sistem norma yang ada. Interaksi itu muncul sebagai bentuk reaksi masyarakat atas diterapkannya sebuah ketentuan perundang-undangan positif dan bisa pula dilihat prilaku masyarakat sebagai bentuk aksi dalam memengaruhi pembentukan sebuah ketentuan hukum positif. kajian sosiologi hukum adalah suatu 
kajian yang objeknya fenomena hukum, tetapi menggunakan optik ilmu sosial dan teori-teori sosiologis, sehingga sering disalahtafsirkan bukan hanya oleh kalangan non hukum, tetapi juga dari kalangan hukum sendiri.

Hukum adat merupakan hukum asli Indonesia yang tidak terkodifikasi dalam peraturan perundang-undangan nasional. Hukum adat merupakan hukum tradisional masyarakat yang merupakan perwujudan dari suatu kebutuhan hidup yang nyata serta merupakan salah satu cara pandangan hidup yang secara keseluruhannya merupakan kebudayaan masyarakat tempat hukum adat tersebut berlaku. Hukum adat juga merupakan nilai-nilai yang hidup dan berkembang di dalam masyarakat suatu daerah. Ada sanksi tersendiri dari masyarakat jika melanggar aturan hukum adat.

Dibawah ini dapat kita pahami perbedaan antara Antropologi hukum dengan beberapa bidang ilmu sosial lainnya dalam ilmu hukum, seperti dengan sosiologi hukum dan hukum adat.

\section{Perbedaan Antropologi Hukum dengan Sosiologi Hukum}

\section{a. Kajian}

Jika dibedakan pada dasar kajiannya, antropoligi hukum Mengkaji hukum dengan mempelajari hukum dengan latar belakang budayanya seperti sejarah,lingkungan hidup, keluarga, pemukiman, politik dan sebagainya. Sedangkan Sosiologi hukum Mengkaji hubungan timbal balik antara hukum dan gejala sosial yg ada di dalam masyarakat yang dilakukan secara analitis dan empiris (sesuai dengan kenyataannya).

b. Kelebihan dan Kekurangan

Masing-masing kajian Ilmu tentu memiliki kelebihan dan kekurangannya, dalam hal ini kelebihan yang dimiliki oleh antropologi hukum ialah melalui kajian antropolgi maka hukum dapat di ketahui latar belakang kebudayaanya, dan 
menghasilkan pola dan penyelesaian dari pada sengketa-sengketa yang terjadi di dalam masyarakat. Sedangkan kelebihan sosiologi hukum adalah objek yang di kaji benarbenar sesuai kenyataan, dan tidak bersifat spekulatif, serta diketahui faktor yang menyebabkan masyarakat patuh atau tidak mentaati hukum tersebut.

Kekurangan dari antropologi hukum ialah terletak pada ketidak seragamannya hukum dan proses penyelesaian masalah karena berdasarkan latar belakang kebudayaan dari hukum itu sendiri. Pada sosiologi hukum memiliki kekurangan hanya sebatas mengkaji hubungan timbal balik antar hukum dengan gejala sosial akan tetapi tidak mengkaji faktor yang menyebabkan penyimpangan dari hukum itu sendiri.

c. Proses

Ditinjau dari segi proses, perbedaan kedua bidang ilmu ini adalah. Pada antropologi hukum, proses awalnya ialah temukan dulu faktanya (Social facts), kemudian dipilahpilah mana yang merupakan budaya hukum, lalu dibuat konstruksi hukumnya dan terakhir dianalisis untuk ditemukan maknanya yang mempunyai ciriciri khusus, sebagai penjabaran dari jalinan nilai budaya. Sedangkan pada sosiologi hukum, proses awalnya ditemukan faktanya (social facts) kemudian dipilahpilah mana yang merupakan kenyataan hukum lalu dibuat konstruksi hukumnya, selanjutnya dianalisis dengan perundang-undangan/kaedah hukumnya, terakhir disimpulkan.

Selain dari hal diatas dalam beberapa hal sederhana lain terdapat perbedaan antara antropologi hukum dengan sosiologi hukum, seperti dalam perspektif dan objek pada bidang ilmu ini. Perspektif pada antropolgi hukum ialah budaya, namun pada sosiologi perspektifnya adalah sosial. Sedangkan pada bagian objek, antropologi hukum objeknya ialah Hukum bukan 
Barat, Tidak tertulis, dan objek sosiologi hukum adalah Hukum barat / yang telah dipengaruhi hukum tertulis.

Dalam perkembangan selanjutnya, kedua ilmu itu dapat saling melengkapi bahkan melebur diri menjadi satu ilmu. Pada universitas tertentu, antropologi dan sosiologi merupakan program studi yang dikembangka secara bersama-sama di bawah departemen antropologi-sosiologi atau sosiologi-antropologi.

Namun ada pihak lain yang masih tetap mempertahankan adanya perbedaan antara antropologi dan sosiologi. Secara historis, kemunculan kedua ilmu tersebut adalah berbeda baik dari segi paradigma yang digunakan, metode yang digunakan atau pun sasaran masyarakat yang menjadi obyek penelitiannya. Di mana antropologi menekankan kajiannya pada masyarakat tradisional di luar masyarakat Barat, sedangkan sosiologi lebih menekankan pada masyarakat perkotaan yang pada saat itu ada pada masyarakat Barat sendiri.

\section{Perbedaan Antropologi Hukum dengan Hukum Adat}

Hukum adat yang diutamakan adalah identifikasi dari adat yang mempunyai konsekuensi hukum. Sedangkan Antropologi Hukum, disamping mempelajari norma hukum juga ditelaah berbagai jenis pedoman perilaku serta hubungan di antara aneka norma itu dengan nilai-nilai budaya yang dianut dalam suatu masyarakat. Jadi dapat dikatakan bahwa wawasan Antropologi Hukum lebih luas karena tidak hanya memperhatikan hukum di Indonesia, tetapi juga bersifat komparatif sehingga hukum ditinjau sebagai gejala yang bersifat lintas budaya.

Obyek antropologi hukum adalah perilaku hukum dari manusia, sedangkan sasarannya adalah norma-norma hukum yang dipakai oleh anggota masyarakat. Selanjutnya pendekatan yang dipakai antropologi hukum adalah holistik, dari kata whole, 
artinya dalam mempelajari sesuatu akan dilihat secara keseluruhan. Meminjam teori sistem, hukum hanyalah entitas sub sistem yang dipengaruhi dan mempengaruhi oleh sub-sub sistem yang lain, misalnya sub sistem ekonomi, sub sistem politik, sub sistem sosial dan lain sebagainya. Kemudian dilihat dari sifat penelitian, pada Antropologi Hukum lebih menitikberatkan pada penelitian lapangan (field research) dari pada studi pustaka. Sebaliknya hukum adat, lebih mengutamakan studi pustaka dan dokumen dari pada penelitian lapangan.

\section{PENUTUP}

Antropologi hukum dan Sosiologi hukum memiliki objek yang jelas yakni manusia. Antropologi hukum menelaah atau mempelajari kebudayaan diantara kelompok masyarakat, sedangkan sosiologi hukum lebih berfokus pada manusia dan berbagai proses hubungan sosial dalam masyarakat tersebut. Adanya antropologi hukum dan sosiologi hukum diharapkan membuat kehidupan masyarakat menjadi lebih tertib dan teratur. Dalam berbagai bentuk penyimpangan sosial memang kerap kali terjadi di lingkungan masyarakat, namun ada banyak langkah pencegahan yang bisa dilakukan dan salah satunya dengan mempelajari ilmu sosiologi hukum serta ilmu antropologi hukum.

Dalam perbedaan yang ada nyatanya Hukum adat memerlukan ilmu antropologi hukum, terutama mengenai metode-metode penelitiannya, agar dapat mengkaji dan meneiliti tentang latar belakang hukum adat yang berlaku di suatu daerah. data antropologi hukum akan dapat mengidentifikasikan nilai-nilai yang menjadi dasar dari hukum adat. Di satu pihak data antropologi hukum akan dapat memberikan data mengenai budaya hukum Indonesia, sedangkan 
di lain pihak studi hukum adat akan dapat memberikan data mengenai bidang-bidang mana yang dapat diseragamkan dan bidang mana seyogianya dibiarkan bervariasi.

\section{DAFTAR PUSTAKA}

Darmini Roza dan Laurensius Arliman S, Peran Pemerintah Daerah Di Dalam Melindungi Hak Anak Di Indonesia, Masalah-Masalah Hukum, Volume 47, Nomor 1, 2018. https://doi.org/10.14710/mmh.47.1.2018.10-21

Laurensius Arliman S, Peranan Metodologi Penelitian Hukum di Dalam Perkembangan Ilmu Hukum di Indonesia, Soumatera Law Review, Volume 1, Nomor 1, 201. http://doi.org/10.22216/soumlaw.v1i1.3346.

Laurensius Arliman S, Peran Badan Permusyawaratan Desa di Dalam Pembangunan Desa dan Pengawasan Keuangan Desa, Padjadjaran Journal of Law, Volume 4, Nomor 3, 2017. https://doi.org/10.15408/jch.v4i2.3433.

Laurensius Arliman S, Penanaman Modal Asing Di Sumatera Barat Berdasarkan Undang- Undang Nomor 25 Tahun 2007 Tentang Penanaman Modal, Supremasi Hukum, Volume 1, Nomor 1, 2018. http://dx.doi.org/10.36441/hukum.v1i01.102 .

Laurensius Arliman S, Memperkuat Kearifan Lokal Untuk Menangkal Intoleransi UmatBeragama Di Indonesia, Ensiklopedia of Journal, Volume 1, Nomor 1, 2018, https://doi.org/10.33559/eoj.v1i1.18.

Laurensius Arliman S, Perkawinan Antar Negara Di Indonesia Berdasarkan Hukum Perdata Internasional, Kertha Patrika, Volume 39, Nomor 3, 2017, https://doi.org/10.24843/KP.2017.v39.i03.p03.

Laurensius Arliman S, Partisipasi Masyarakat Di Dalam Pengelolaan Uang Desa PascaUndangUndang Nomor 6 Tahun 2014 Tentang Desa, Jurnal Arena Hukum, Volume 12, Nomor 2, 2019, https://doi.org/10.21776/ub.arenahukum.2019.01202.5.

Laurensius Arliman S, Mewujudkan Penegakan Hukum Yang Baik Di Negara Hukum Indonesia, Dialogica Jurnalica, Volume 11, Nomor 1, 2019, https://doi.org/10.28932/di.v11i1.1831.

Laurensius Arliman S, Mediasi Melalui Pendekatan Mufakat Sebagai Lembaga Alternatif Penyelesaian Sengketa Untuk Mendukung Pembangunan Ekonomi Nasional, UIR Law Review, Volume 2, Nomor 2, 2018, https://doi.org/10.25299/uirlrev.2018.vol2(02).1587

Laurensius Arliman S, Peranan Filsafat Hukum Dalam Perlindungan Hak Anak Yang Berkelanjutan Sebagai Bagian Dari Hak Asasi Manusia, Doctrinal, Volume 1, Nomor 2,2016.

Laurensius Arliman S, Ni Putu Eka Dewi, Protection of Children and Women's Rights in Indonesiathrough International Regulation Ratification, Journal of Innovation, Creativity and Change Volume 15, Nomor 6, 2021. 
Laurensius Arliman S, Gagalnya Perlindungan Anak Sebagai Salah Satu Bagian Dari Hak Asasi Manusia Oleh Orang Tua Ditinjau Dari Mazhab Utilitarianisme, Jurnal Yuridis, Volume 3, Nomor 2, 2016, http://dx.doi.org/10.35586/.v3i2.180.

Laurensius Arliman S, Tantangan Pendidikan Kewarganegaraan Pada Revolusi 4.0, Jurnal Ensiklopedia Sosial Review, Volume 2, Nomor 3, $2020 .$. 